\title{
A complex of treatment facilities for the neutralization of surface run-off from urban territories
}

\author{
Oleg Primin", Galina Varyushina and Andrey Ten \\ Moscow State University of Civil Engineering, Yaroslavskoe shosse, 26, Moscow, 129337, Russia
}

\begin{abstract}
Surface run-off from developed urban territories, be it orderly disposed surface run-off or diffused surface run-off, is among the main sources of man-made pollution and degradation of urban water bodies located within the boundaries of Moscow. In the present-day context, the improvement of their ecological condition is possible only in case of implementation of measures aimed at the reduction of human-induced impact on water bodies, elimination of accumulated environmental damage, recovery of their self-purification ability and groundwater protection against pollution. The authors give the results of the seasonal monitoring of surface run-off composition and the composition of sludge produced by the treatment facilities located on urban territories of different functional purpose. The studies proved the idea that the application of polymeric flocculants intensifies the process of dewatering the sludge produced by treatment facilities in different seasons. The criteria characterizing the main efficiency indices for the selection of technological approaches and equipment, were developed based on generalized and summarized experience in seasonal observations and evaluation of process and hydraulic parameters of the operation of surface run-off treatment facilities.
\end{abstract}

\section{Introduction}

Centralized collection and treatment of surface run-off is a vital environmental goal. Research studies revealed that surface run-off from developed territories of cities and other settlements, be it orderly disposed surface run-off or diffused surface run-off, is among the main sources of human-induced pollution and degradation of urban water bodies [1]. A special feature of the system for surface run-off disposal and treatment in Moscow is a large-scale usage of urban hydrographic network as some elements of urban drainage network, which is a system of sewers and rivers for the collection and transportation of atmospheric and environmental water. The water catchment area amounts to 61.2 thousand ha, and about 600 million $\mathrm{m}^{3}$ of wastewater is annually disposed into the urban network of sewers and rivers. The surface run-off drainage system of Moscow is operated by "Mosvodostok" SUE, which is in charge of the following:

- Surface run-off drainage network, 7.4 thousand km long; it has 110 thousand surface runoff inlets and 160 thousand inspection manholes

*Corresponding author: tepper2007@yandex.ru 
- Water bodies - small rivers and water reservoirs, 211 in number, of 690 ha total area; the length of open river and brook channels is about $250 \mathrm{~km}$

- Surface run-off disposal network of the Moscow Circular Highway and the Third Ring Road

- Likhoborskaya Water Replenishment System for the replenishment of water in the Yauza River

- Hydraulic structure on the Yauza River that fills up the Moskva River with water

- 13 snow-melters for the utilization of snow removed from urban streets and highways in winter.

\section{Methods}

At present the operating conditions of the municipal surface run-off drainage system in Moscow differ considerably from the design conditions of this system. The weather conditions and precipitation intensity have changed and the volume of surface run-off increased correspondingly. As a result of road and sidewalk surfacing reconstruction, the percentage of water-impervious surfaces increased (asphalt pavements of highways, driveways and parking areas, territories built-over with multi-storied apartment houses and office buildings, shopping and recreational centers), while the percentage of water-permeable surfaces (lawns, public gardens, parks, river flood-plains and nature sanctuaries) was reduced drastically [2]. Apart from that, the number of vehicles in cities is growing constantly, resulting in a considerably greater pollution of surface run-off with heavy metals, mechanical impurities, mineral oils, de-icing agents and the surfactants applied for street flushing and watering. In particular, Figure 1 shows the dynamics of surface run-off heavy-metal concentration variations depending on different seasons and types of urban territories.

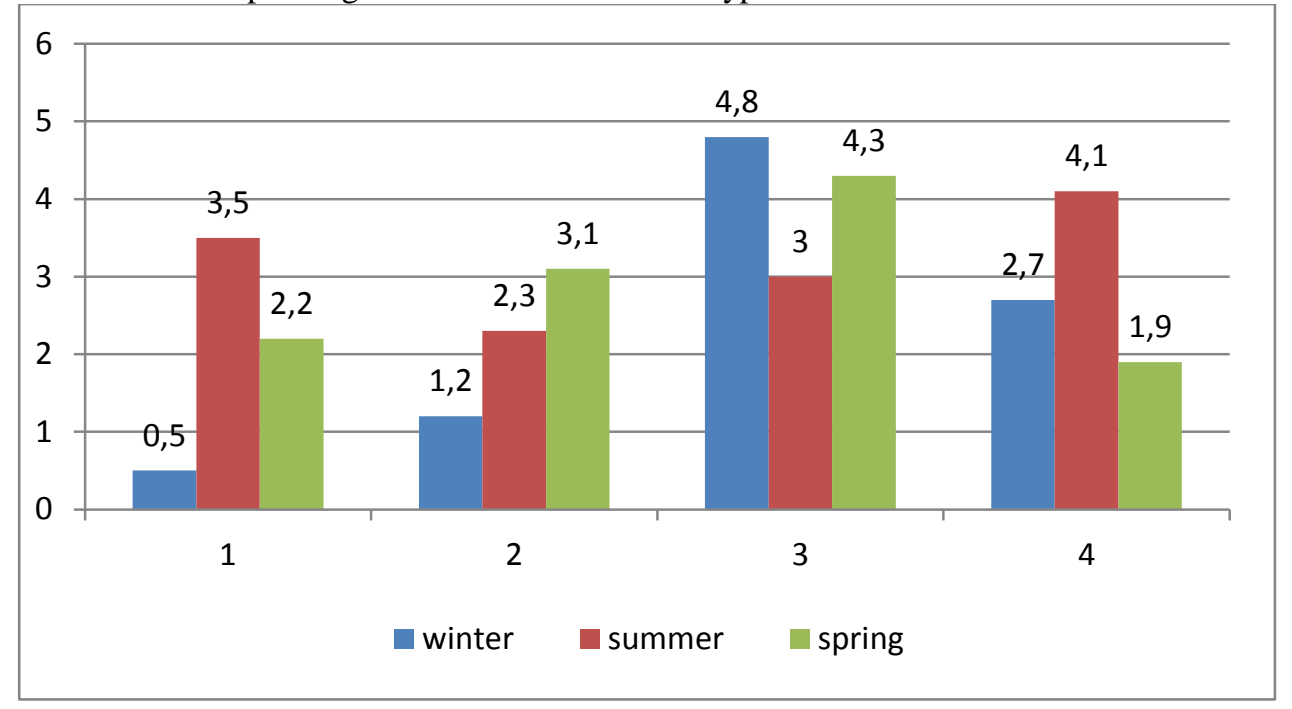

Fig. 1. The dynamics of surface run-off heavy-metal concentration (mg/l) variations depending on different seasons and types of urban territories, 2015 - 2017: 1 - bus depots; 2 - residential area; 3 fuel-filling stations; 4 - construction companies

In most cases, the discharge outlets of the Moscow surface run-off drainage system that open into the water bodies, are not equipped with estuarine treatment facilities, while the existing treatment facilities are outdated being unable to provide the level of surface run-off 
treatment and neutralization required by the current standards established for fishery water bodies. The increase in the average annual volume of surface run-off up to 690 million $\mathrm{m}^{3}$ and consequently, the growth of the human-induced impact on urban water bodies, requires a large-scale construction of new treatment facilities and the reconstruction of existing treatment facilities of the system for surface run-off disposal and treatment. The analysis of treatment patterns used by the existing treatment facilities in Moscow revealed (Table 1) that the residual concentrations of suspended solids in treated wastewater, as a rule, exceed twice or thrice (sometimes even ten times for certain treatment facilities) the maximum permissible concentration for fishery water bodies $\left(\mathrm{MPC}_{\mathrm{fw}}\right)$; as to petroleum products, their concentrations may exceed the value of $\mathrm{MPC}_{\mathrm{fw}}$ some 60 times or more [3]. The dynamics of changes in the qualitative composition of water in the Moskva River within the city boundaries (the river section between the point where the river enters the city and the point where the river crosses the Moscow Circular Highway in the vicinity of the Besedinsky Bridge) revealed that at the point where the Moskva River enters the city, the water in this river meets the water-quality requirements established by the standards for fishery water bodies [4] only with regard to the concentrations of chlorides, sulphates and (as a rule) suspended solids. All other monitored pollution values are above the limits. With regard to petroleum products, the values exceed $\mathrm{MPC}_{\mathrm{fw}}$ some 4.4 times; for ammonia nitrogen, the $\mathrm{MPC}_{\mathrm{fw}}$ is exceeded 3.7 times, while for $\mathrm{BOD}_{5}$ the $\mathrm{MPC}_{\mathrm{fw}}$ value is exceeded some 2.6 times [5]. Table 1 contains the results of the efficiency of surface run-off treatment provided by different types of treatment facilities.

Table 1. Surface run-off treatment efficiency provided by the existing treatment facilities in Moscow with regard to main pollutants

\begin{tabular}{|c|c|c|c|c|}
\hline \multirow[b]{2}{*}{$\begin{array}{l}\text { Surface run-off } \\
\text { treatment facili- } \\
\text { ties }\end{array}$} & \multicolumn{2}{|c|}{ Suspended solids } & \multicolumn{2}{|c|}{ Petroleum products } \\
\hline & $\begin{array}{l}\text { Residual con- } \\
\text { centration, mg/l }\end{array}$ & $\begin{array}{c}\text { Treatment } \\
\text { effect, \% }\end{array}$ & $\begin{array}{c}\text { Остаточная } \\
\text { концентрация, } \\
\text { mg/l }\end{array}$ & $\begin{array}{c}\text { Treatment } \\
\text { effect, \% }\end{array}$ \\
\hline $\begin{array}{l}\text { Mechanical treat- } \\
\text { ment facilities } \\
\text { (sedimentation } \\
\text { basins equipped } \\
\text { with devices for } \\
\text { the removal of } \\
\text { petroleum prod- } \\
\text { ucts) }\end{array}$ & Up to $10-20$ & $20-40$ & Up to 3.0 & $10-15$ \\
\hline $\begin{array}{l}\text { Chamber-type } \\
\text { treatment facilities } \\
\text { (underground } \\
\text { flow-through ves- } \\
\text { sels equipped with } \\
\text { filter cassettes) }\end{array}$ & Up to $10-20$ & Up to 70 & Up to 3.0 & $10-15$ \\
\hline $\begin{array}{l}\text { Treatment facilities } \\
\text { equipped with } \\
\text { thin-layer modules }\end{array}$ & Up to $30-40$ & $40-60$ & Up to 10 & Up to 60 \\
\hline $\begin{array}{l}\text { Gabion filtration } \\
\text { treatment facilities } \\
\text { (equipped with a } \\
\text { filtering Gabion }\end{array}$ & Up to $50-100$ & $10-20$ & Up to 20 & $5-10$ \\
\hline
\end{tabular}




\begin{tabular}{|l|l|l|l|l|}
\hline dam) & & & & \\
\hline $\begin{array}{l}\text { Cluster treatment } \\
\text { facilities compris- } \\
\text { ing reagent treat- } \\
\text { ment }\end{array}$ & Up to 5-8 & $80-90$ & $0.5-1.0$ & $80-90$ \\
\hline $\begin{array}{l}\text { Advanced treat- } \\
\text { ment facilities } \\
\text { (provided with } \\
\text { sorption advanced } \\
\text { treatment) }\end{array}$ & Up to 1-5 & $90-95$ & $0.03-0.1$ & $90-95$ \\
\hline
\end{tabular}

At the point where the Moskva River exits Moscow, the concentration of petroleum products in the river water exceeds $\mathrm{MPC}_{\mathrm{fw}}$ up to 6 times; the concentration of ammonia nitrogen exceeds the $\mathrm{MPC}_{\mathrm{fw}} 21.6$ times, while the $\mathrm{BOD}_{5}$ value exceeds the $\mathrm{MPC}_{\mathrm{fw}}$ some 3.6 times, thus making it clear that the water in the main river of Moscow is polluted with wastewater, including insufficiently treated and untreated surface run-off from the water catchment area of the city (both orderly-disposed surface run-off and diffused surface runoff).

The federal Russian surface run-off quality standards have been developed and approved for every water use category: drinking and household water use, cultural and social (recreational) water use and fishery water use. They comprise general requirements for the composition and properties of water in water-sources, as well as the list of maximum permissible concentrations (MPC) of harmful substances in the water of water bodies. There are 1065 valid $\mathrm{MPC}_{\mathrm{fw}}$ standards for fishery water bodies and 1383 valid sanitary standards $\mathrm{MPC}_{\mathrm{san}}$. Under the existing conditions any improvement in the ecological condition of water bodies is possible only in case the following measures are implemented: reduction in human-induced impact on water bodies and their water catchment areas, elimination of accumulated environmental detriment, recovery of the self-purification capabilities of water bodies, and groundwater protection against pollution.

\section{Results}

As a result of multi-year laboratory-scale and full-scale research in pursuit of the best methods for surface run-off neutralization, the authors have developed a special combination of detention-type facilities for surface run-off neutralization. These facilities are suitable for territories of different functional purpose that have different-size water catchment areas, for example: residential districts, industrial enterprises, motorways, parklands, recreational areas, mixed-development zones, etc. Figure 2 shows the process flow diagram for the mechanical, physical and chemical treatment of surface run-off and the sludge produced as a result of its treatment. 


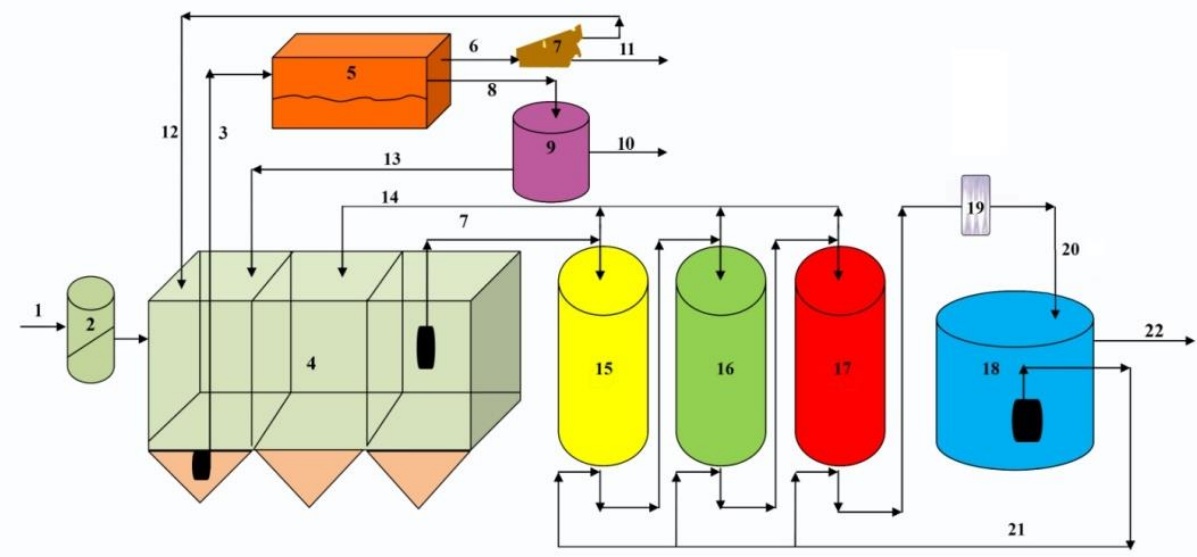

Fig. 2. Process flow diagram for surface run-off treatment: 1- polluted surface run-off; 2- a well equipped with a trash-rack; 3 - raw sludge; 4 - retention basin; 5 - sludge thickener; 6 - thickened sludge for the chamber filter-press; 7- chamber filter-press; 8 - supernatant liquor; 9 - oil separator; 10 - crude oil sludge to be utilized; 11- dewatered sludge to be utilized; 12 - filtrate water to be treated; 13 - polluted water; 14 - polluted wash-water; 15 - primary filter; 16 - secondary filter; 17 - IIIstage filter; 18 - treated surface run-off vessel; 19 - bactericidal unit; 20 - treated surface run-off; 21treated water for filter-bed washing; 22 - treated surface run-off disposal into a water body or a centralized water disposal system.

The process and hydraulic calculations for the networks and facilities were carried out in accordance with the guidance manual [6], which is a supplement to the Construction Regulations SP 32.13330.2012. Wastewater Disposal and Treatment. External Networks and Facilities. Revised Edition of SNiP 2.04.03-85. The above-mentioned combination of facilities is designed for the all-year-round neutralization of surface run-off from the water catchment area, this surface run-off having a multi-component pollution composition. Atmospheric run-off enters the drainage mains through the storm-water intake screens located on the territory according to vertical land leveling. After that it enters the underground detention tank. To provide the gravity-flow disposal of surface run-off, the facilities should be located at the lowest level of the water catchment area. The complex of surface run-off treatment comprises the following facilities:

- Inspection manhole equipped with a trash rack to trap fine rubbish. This trash rack is installed in the sewer that delivers surface run-off to the treatment facilities

- Horizontal-flow sand trap to trap sand, settling solids and particulate pollutants; the sand trap is equipped with a catch-pit for precipitate

- Rectangular detention vessel sectioned with longitudinal partitions; overflow openings are located in the upper part of these partitions to remove suspended solids and emulsified petroleum products

- A three-stage cascade of pressure filters having fine-grained filter and sorption beds for advanced surface run-off treatment including the removal of fine-dispersed suspensions, colloid and dissolved impurities, aromatic and organic chlorine compounds, phenols, benzenes, heavy-metal ions, nutrients and surfactants

- Disinfection unit equipped with a bactericidal ultra-violet device to remove pathogenic micro-organisms and to disinfect treated surface run-off 
- Treated surface run-off vessel to accumulate water and to use it for the technical needs of the treatment facilities, including the washing of mechanical treatment facilities and filter beds

- Gravity-flow thickener of sludge accumulated in the grit chamber and detention tank is used for sludge primary dewatering and its volume reduction

- Oil separator for the collection and accumulation of floating petroleum products

- Chamber filter press equipped with a bin for dewatered sludge storage

- Treated surface run-off outlet for its discharge into a water body or a centralized wastewater disposal system.

Table 2 contains the results of laboratory and in-process monitoring [7, 8] of the surface run-off treatment facilities located on the territory of a bus depot in Moscow.

Table 2. The efficiency of surface run-off treatment by the treatment facilities of a bus depot in Moscow

\begin{tabular}{|l|l|l|l|}
\hline $\begin{array}{c}\text { Surface run-off com- } \\
\text { position index }\end{array}$ & $\begin{array}{c}\text { Concentration of pol- } \\
\text { lutants in raw surface } \\
\text { run-off, mg/l }\end{array}$ & $\begin{array}{c}\text { Concentration of pol- } \\
\text { lutants in treated sur- } \\
\text { face run-off, mg/l }\end{array}$ & $\begin{array}{c}\text { MPC of pollutants } \\
\text { in water to be dis- } \\
\text { charged into a fish- } \\
\text { ery water body }\end{array}$ \\
\hline Aluminium & 3.56 & 0.023 & 0.04 \\
\hline BOD $_{5}$ & 8.63 & 2.19 & 3.0 \\
\hline Suspended solids & 256.0 & 3.0 & 3.0 \\
\hline Iron & 9.715 & 0.047 & 0.1 \\
\hline Cadmium & 0.972 & 0.001 & 0.005 \\
\hline Manganese & 0.973 & 0.006 & 0.01 \\
\hline Copper & 1.295 & 0.001 & 0.001 \\
\hline Petroleum products & 62.9 & 0.03 & 0.05 \\
\hline Nickel & 1.274 & 0.007 & 0.01 \\
\hline Total salt content & 670.3 & 645.28 & 1000.0 \\
\hline pH medium & 7.2 & 7.6 & $6.5-8.5$ \\
\hline Lead & 2.698 & 0.002 & 0.006 \\
\hline $\begin{array}{l}\text { Anionic synthetic } \\
\text { surfactants }\end{array}$ & 5.743 & 0.005 & 0.01 \\
\hline Sulphates & 91.67 & 83.94 & 100.0 \\
\hline Chlorides & 218.34 & 196.15 & 300.0 \\
\hline COD & 45.09 & 10.72 & 30.0 \\
\hline Chromium +3 & 0.862 & 0.015 & 0.07 \\
\hline Chromium +6 & 0.173 & 0.36 & 0.02 \\
\hline Zinc & 1.546 & 0.008 & 0.01 \\
\hline & & & \\
\hline
\end{tabular}

To meet the existing requirements for treated surface run-off disposal into water bodies, the treatment technology should meet the following criteria:

- Complex neutralization of wastewater, including efficient methods for water, sludge and oil-sludge treatment, as well as treated wastewater disinfection prior to its discharge into water bodies

- Application of technologies developed taking into account the treatment of melt water polluted with de-icing agents

- Automation of sludge treatment processes and providing them with the devices for operational data transmission to the central control room. 
- Automated monitoring of the operation of surface run-off treatment facilities through the application of wastewater quality analyzers

- Providing the instruments for the control of the volumes of water, sludge and oil-sludge being treated

- Application of energy-saving equipment, innovative devices, instruments and materials

- Expedient solutions and measures that make it possible to use treated wastewater for technical purposes (highway watering and cleaning in summer, greenery watering, etc.) [9] in accordance with the existing environmental protection requirements

- All top-priority monitored indices for treated water quality must meet the requirements established [10] by the existing standards for treated wastewater disposal into fishery water bodies (including the indices for nutrients and heavy metals)

- Calculating the annual cost of the operation of proposed treatment facilities, the cost of measures on its minimization and the treatment cost for $1 \mathrm{~m}^{3}$ of wastewater

- Development of engineering proposals aimed at optimizing the cost of construction operations for the development of a longer lifetime treatment system.

\section{Conclusions}

1. In order to meet the requirements established by Russian environmental protection legislation with regard to treated surface run-off disposal into water bodies, it is recommended to use retention-type facilities, advanced treatment through the application of physical and chemical methods as well as disinfection prior to the disposal of treated surface run-off into water bodies or centralized wastewater disposal systems.

2. Laboratory-scale experiments on studying the dewatering properties of surface runoff sludge revealed that a chamber filter press is an efficient dewatering tool if a solution of Praestol $852(1.5-3 \mathrm{mg} / \mathrm{l})$ is preliminary added to this sludge. The residual water content was some 63 - 65 percent. When selecting the optimal dewatering equipment, it is expedient to use low-duty mechanical installations of Russian or foreign make. It is also required to take into account the particularities of surface run-off formation, sludge composition and properties, as well as the requirements for the subsequent reuse of dewatered product or its disposal to dumping sites.

3. It is recommended to compare and select the technologies for surface run-off neutralization on the basis of given criteria, that may comprehensively characterize the types of treatment facilities offered by manufacturing companies. The treatment efficiency with regard to standardized indices should be tested and evaluated based on the actual values of surface run-off composition obtained as a result of on-site sampling.

\section{References}

1. O.G. Primin, G.P. Varyushina, L.M. Vereshchagina. Protection of water bodies from pollution by surface sewage. The municipal complex of Russia, 7, 36 - 40, (2017)

2. G.P. Varyushina. Modern experience in the operation of complexes for cleaning surface wastewater. Water treatment, 1, $24-28$, (2014)

3. G. P. Varyushina, N. V. Sveshnikova. The Ways for the Modernization of Surface RunOff Treatment Facilities. Water Supply \& Sanitary Engineering, 5, 35 - 39, (2017)

4. Order of the Ministry of Agriculture of the Russian Federation 552 of 13.12.2016 "Concerning the Approval of Water Quality Standards for Fishery Water Bodies, In- 
cluding the Standards for Maximum Permissible Concentrations of Hazardous Substances in the Water of Fishery Water Bodies" (2016)

5. Russian Sanitary Standards and Regulations SanPiN 2.1.5.980-00. Wastewater Disposal from Inhabited Localities, Sanitary Protection of Water Bodies. Sanitary Requirements for Surface Water Protection (2000)

6. Guidance Manual "Recommendations for the Collection, Disposal, and Treatment of Surface Run-Off from Residential Areas and Industrial Sites and for Determining the Conditions for Surface Run-Off Disposal into Water Bodies”. Obligatory Supplement to Construction Regulations SP 32.13330.2012. “Wastewater Disposal. External Networks and Facilities" (with amendment 1, approved 30.12.2015 by the Order of the Ministry of Construction N 986/pr) (2012)

7. GOST 31861-2012. Water. General requirements for sampling (2012)

8. MU 2.1.5.1183-03 Sanitary and epidemiological supervision of water use in technical water supply systems of industrial enterprises (2003)

9. E. I. Pupyrev. The Choice of water purification technology in modern economic conditions. Water supply and sanitary engineering, 12, 29 -37, (2012)

10. V. G. Ponomarev. Evaluation of the characteristics of the contaminants in the choice of methods of wastewater treatment. Water supply and sanitary technique, 5, 50 -57, (2015) 